Vol 1 No 12020 Juli 2020

Jurnal AlphaEuclidEdu

Received: 07/07/2020; Revised: 28/07/2020; Accepted: 29/07/2020

\title{
KEMAMPUAN KOMUNIKASI MATEMATIS DIKAJI DARI SELF-ESTEEM SISWA PADA MATERI HIMPUNAN
}

\author{
${ }^{1}$ Elviani, Dina, ${ }^{2}$ Sugiatno, ${ }^{3}$ Sayu, Silvia \\ ${ }^{1,2,3}$ Pendidikan Matematika FKIP Universitas Tanjungpura Pontianak \\ dinaelviani@gmail.com
}

\begin{abstract}
This study aims to find out how students' mathematical communication skills in solving sets of questions that have high, medium, and low self-esteem, in class VII of SMP Islam Bawari in Pontianak. This study used a descriptive qualitative research method with a survey form. The subjects of this research is 29 students in class VIIB SMP Islam Bawari Pontianak. Test and non-test techniques are used in this study as data collection techniques. Self-esteem questionnaire test, mathematical communication ability test, and interview are the tools used in this research. The results of this study are students with a high level of self-esteem that have fulfilled the category of mathematical communication skills, including that students are relatively able to understand the context of the problem in presenting the information obtained from the problem; Students with moderate levels of self-esteem almost meet the category of mathematical communication skills, This is indicate that students have a difficulty in solving problems, so the answers given are incomplete and inaccurate with the information contained in the questions; Students with low levels of self-esteem barely meet the category of communication skills, This is indicate that students have a difficult in understanding the purpose of the question.
\end{abstract}

Keywords: Material of Set, Mathematical Communication Skills, Self-Esteem

\section{Pendahuluan}

Beberapa peneliti matematika mulai peduli dengan self-esteem siswa. Adapun Studi tentang self-esteem, antara lain yang menyatakan bahwa antara self-esteem dengan prestasi belajar terdapat korelasi yang signifikan dan searah yaitu jika self-esteem yang dimiliki siswa tinggi maka tinggi pula prestasi belajar yang diperolehnya (Yeshodhara dan Vishalakshi, 2012) .

Lackner (2015) juga melakukan penelitian mengenai meta-analisis yang menyelidiki korelasi antara harga diri dan prestasi akademik. Ditemukan bahwa self-esteem (harga diri) berkontribusi sebesar 13\% terhadap prestasi akademik siswa. Verdianingsih (2017) melakukan penelitian mengenai self-esteem dalam pembelajaran matematika. Ditemukan bahwa self-esteem dapat meningkatkan prestasi belajar khususnya dalam pembelajaran matematika.

Berdasarkan penelitian yang sudah dilakukan oleh Yeshodhara dan Vishalakshi (2012), Lackner (2015), dan Verdianingsih (2017) dapat ditarik kesimpulan bahwa self-esteem memiliki peran yang penting dalam pembelajaran matematika dan prestasi akademik siswa. Hendriana dkk (2018: 221) mengemukakan bahwa selfesteem merupakan satu diantara komponen afektif. Happy (2014) menyatakan Selain aspek kognitif aspek afektif juga perlu dikembangkan khususnya self-esteem yang dimiliki tiap siswa sehingga pembelajaran lebih efektif.

Coopersmith (Fadhilla, 2012) mendefinisikan bahwa self-esteem merupakan penilaian individu terhadap kemampuan (capability), keberartian (significane), keberhasilan (successfulness), dan kepantasan (worthess) individu yang diwujudkan berupa sikap yang dimiliki tiap individual terhadap dirinya sendiri.

Adapun indikator dari self-esteem, yaitu: (a) Menunjukkan kesadaran terhadap kekuatan dan kelemahan dirinya; (b) Menimbulkan rasa pecaya diri jika dirinya dibutuhkan orang lain; (c) Menampilkan rasa percaya diri yang dimilikinya bahwa dirinya layak; (d) Menunjukan rasa percaya diri terhadap kemampuannya; (e) Memperlihatkann rasa bangga terhadap hasil yang dicapainya; (f) Menunjukkan keyakinan dirinya dalam memecahkan masalah matematika; (g) Menimbulkan keyakinan bahwa dirinya mampu berkomunikasi matematis (Pujiastuti, 2014). Satu diantara indikator self-esteem yang dikemukakan oleh Pujiastuti (2014) membuat peneliti menduga bahwa self-esteem dapat mempengaruhi kemampuan komunikasi matematis, adapun indikatornya yaitu: siswa dapat menunjukkan keyakinan bahwa dirinya mampu berkomunikasi matematis.

Dokumen National Council of Teacher of Mathematics (NCTM, 2000: 60) menyatakan bahwa komunikasi merupakan suatu bagian esensial dari matematika dan pendidikan matematika. Baroody (Umar, 2012) 
Vol 1 No 12020 Juli 2020

Jurnal AlphaEuclidEdu

menyatakan bahwa terdapat dua alasan kenapa komunikasi menjadi satu diantara point utama dalam pembelajaran matematika yaitu: (1) Pada dasarnya matematika merupakan bahasa. Matematika bukan hanya alat berpikir untuk membantu siswa dalam menemukan pola, penyelesaian masalah serta membuat kesimpulan, melainkan juga alat untuk mengkomunikasikan jalan pikiran siswa tentang ide dengan ringkat, tepat dan jelas; (2) pembelajaran matematika merupakan bagian dari kegiatan sosial yang mengimplikasikan setidaknya dua pihak yaitu dapat berupa guru dan murid. Proses belajar mengajar sangat penting untuk siswa dalam mengungkapkan ide-ide dan pemikiran yang dimilikinya dengan cara mengkomunikasikannya kepada orang lain menggunakan bahasa. Namun kenyataannya siswa masih sering kesulitan dalam mengkomunikasikan ide-ide matematisnya.

Berdasarkan hasil dari pengamatan yang dilakukan oleh peneliti pada saat melaksanakan PPL, peniliti menduga bahwa tingkat kemampuan komunikasi matematis siswa masih cenderung kurang. Hal tersebut dibuktikan dengan kurangnya kemampuan komunikasi matematis siswa yang masih jauh dari yang diharapkan. Siswa diindikasi mengalami kesulitan dalam menyelesaikan soal-soal cerita. Masih banyak siswa belum dapat menyampaikan ide-ide matematis yang terdapat pada soal. Ketika siswa diberi beberapa soal yang setara dengan soal sebelumnya tetapi sedikit berbeda dengan contoh soal yang diberikan, siswa belum mampu menyelesaikan soal tersebut dengan baik, sehingga kemampuan komunikasi matematis siswa cenderung belum berkembang secara optimal. Hal ini diperkuat dengan fakta di lapangan ketika peniliti melaksanakan pra-riset. Hasil pra-riset yang telah dilakukan didapat hasil bahwa $60 \%$ siswa masih belum bisa berkomunikasi matematis dengan baik, hal ini sesuai dengan jawaban yang telah siswa kerjakan, dari jawaban siswa secara umum komunkasi matematis yang dimiliki siswa cenderung kurang karena siswa tersebut belum bisa mengubah pernyataan matematik ke dalam bilangan yang ditentukan pada soal himpunan, pemahaman siswa masih kurang, siswa belum mampu menghubungkan ide-ide matematis yang terdapat di soal ke dalam bentuk diagram Venn, pada dasarnya siswa masih belum bisa menggunakan simbol/ notasi/ istilah-istilah yang ada di soal sehingga siswa kesusahan dalam menjawab soal himpunan tersebut.

Berdasarkan masalah yang dipaparkan sebelumnya sehingga peneliti tertarik untuk meneliti judul "Kemampuan Komunikasi Matematis Dikaji dari Self-esteem Siswa Pada Materi Himpunan di Sekolah Menengah Pertama". Dalam penelitian ini sekolah yang dijadikan tempat penelitian adalah di SMP Islam Bawari Pontianak.

\section{Metode Penelitian}

Jenis Secara umum, metode penelitian dapat diartikan sebagai cara yang digunakan oleh peneliti dalam mengumpulkan data penelitiannya (Arikunto, 2009: 160). Metode penelitian pada penelitian ini yaitu metode penelitian deskriptif. Subjek penelitian ini adalah seluruh siswa kelas VIIB SMP Islam Bawari Pontianak yang sudah mempelajari materi himpunan.

Prosedur penelitian merupakan langkah-langkah yang digunakan dalam melakukan kegiatan penelitian. Adapun langkah-langkah yang terdapat pada penelitian ini adalah:

Tahap Persiapan

Tahapan-tahapan yang dilaksanakan pada tahap ini yaitu: (1) Melaksankan pra-riset di SMP Islam Bawari Pontianak pada bulan Februari. Pra-riset dilakukan untuk studi pendahuluan yaitu melakukan tes; (2) Menyiapkan instrumen penelitian berupa angket self-esteem, kisi-kisi soal tes kemampuan komunkasi matematis, soal tes kemampuan komunikasi matematis, alternatif penyelesaian soal tes kemampuan komunikasi matematis, rubrik penilaian tes kemampuan komunikasi matematis, dan kisi-kisi pedoman wawancara; (3) Melaksanakan uji validitas instrumen penelitian; (4) Berdasarkan hasil validitas selanjutnya dilakukan revisi instrument penelitian; (5) Melakukan uji coba angket dan tes kemampuan komunikasi matematis di SMP Mujahidin Pontianak pada tanggal 3 Oktober 2019; (6) Menganalisis data hasil uji coba; (7) Merevisi instrumen penelitian berdasarkan hasil uji coba; (8) Mengatur masalah perizinan penelitian di SMP Islam Bawari Pontianak; (9) Menentukan waktu penelitian dengan guru mata pelajaran matematika kelas VII SMP Islam Bawari Pontianak.

Tahap Pelaksanaan 
Vol 1 No 12020 Juli 2020

Jurnal AlphaEuclidEdu

Tahapan-tahapan yang dilaksanakan pada tahap pelaksanaan yaitu: (1) Memberikan angket self-esteem; (2) Menganalisis hasil angket Self-esteem; (3) Mengelompokkan siswa berdasarkan hasil tes angket self-esteem yaitu tinggi, sedang, dan rendah; (4) Membagikan soal tes essay kemampuan komunikasi matematis; (5) Hasil tes kemampuan komunikasi matematis dianalisis; (6) Memilih subjek penelitian untuk wawancara; (7) Mawawancarai dua orang siswa dari masing-masing kelompok self-esteem sesuai dengan tujuan penelitian dan rumusan masalah sebelumnya. Wawancara dilakukan untuk mendukung jawaban siswa; (8) Mencatat hasil wawancara dalam format wawancara; (9) Mengolah data yang diperoleh secara deskriptif.

\section{Tahap Akhir}

Langkah-langkah pada tahap ini antara lain: (1) Data hasil tes siswa dikumpulkan; (2) Hasil tes data dianalisis; (3) Menganalisis hasil wawancara siswa; (4) Mengurutkan dan melakukan pembahasan berdasarkan analisis data; (5) Membuat kesimpulan dan saran; (6) Menyusunan hasil laporan penelitian.

Teknik tes tertulis, angket, dan wawancara merupakan teknik pengumpulan data pada penelitian ini adalah. Riduwan (2010: 51), menyatakan teknik pengumpulan data adalah teknik atau cara-cara yang dapat digunakan oleh peneliti untuk mengumpulkan data.

\section{Hasil Penelitian dan Pembahasan}

\subsection{Hasil Penelitian}

Hasil penelitian ini didapat dari data tes angket self-esteem, tes kemampuan komunikasi matematis serta wawancara. Tes angket self-esteem diberikan kepada 29 siswa kelas VIIB SMP Islam Bawari Pontianak dengan pernyataan tes angket sebanyak 32 pernyataan. Hasil tes angket self-esteem siswa kelas VIIB SMP Islam Bawari Pontianak dapat dilihat pada Gambar 1 sebagai berikut:

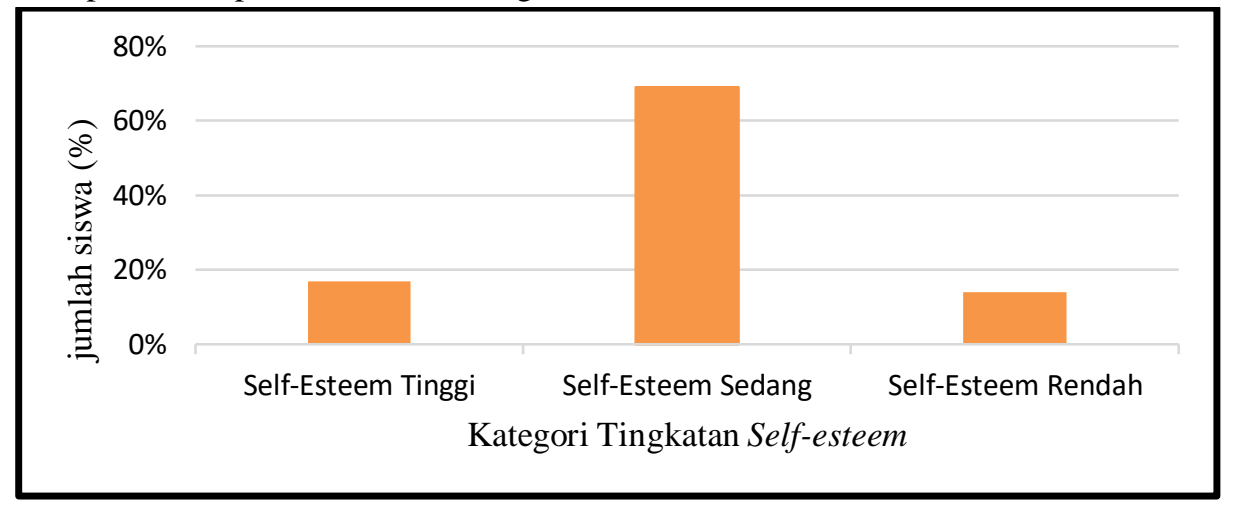

Gambar 1: Hasil Angket Self-Esteem

Hasil angket self-esteem pada gambar 1 diperoleh hasil untuk siswa dengan klasifikasi self-esteem tinggi sebanyak 5 siswa atau sebesar 17\% dengan kode siswa IAK, MNRF, ARS, ANP, dan AZ, sedangkan siswa dengan klasifikasi self-esteem sedang sebesar $69 \%$ atau sebanyak 20 siswa dengan kode siswa SNF, AN, MZ, RS, MT, NPR, F, RR, AJA, AP, AF, INF, NI, FR, KI, D, SS, NLM, MIF, dan M, dan siswa dengan klasifikasi self-esteeem rendah sebanyak 4 siswa atau sebesar 14\% dengan kode siswa VA, MY, WZ, dan S.

Setelah didapat hasil self-esteem yang dimiliki tiap siswa selanjutnya diberikan tes kemampuan komunikasi kepada siswa sebanyak 29 siswa. Tes kemampuan komunikasi matematis berupa tes essay materi himpunan sebanyak 3 soal yang memuat masing-masing dari indikator kemampuan komunikasi matematis tersebut. Dari hasil tes kemampuan komunikasi matematis siswa kelas VIIB SMP Islam Bawari Pontianak dapat dilihat pada Gambar 2 sebagai berikut: 
Vol 1 No 12020 Juli 2020

Jurnal AlphaEuclidEdu

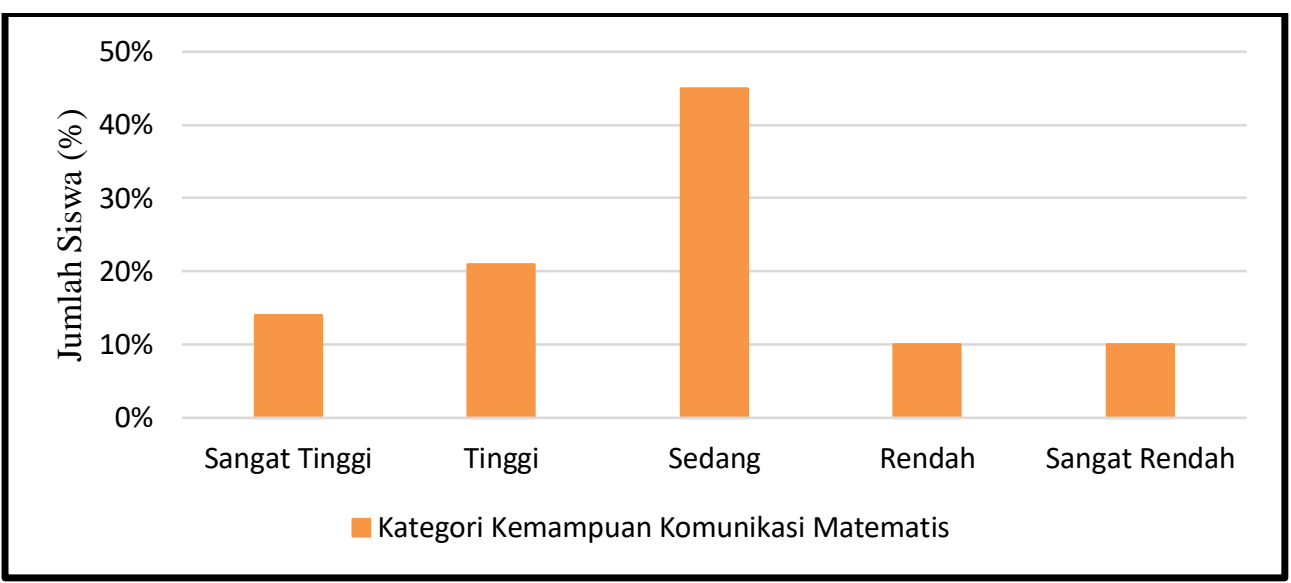

Gambar 2: Hasil Tes Kemampuan Komunikasi Matematis Siswa

Hasil tes kemampuan komunikasi matematis pada gambar 2 diperoleh hasil untuk siswa dengan kemampuan komunikasi matematis sangat tinggi sebanyak 4 orang atau sebesar $14 \%$ yaitu siswa dengan kode NI, ANP, IAK, dan NLM. Sedangkan siswa dengan kemampuan komunikasi matematis tinggi sebanyak 6 orang atau sebesar $21 \%$ yaitu siswa dengan kode MNRF, ARS, AZ, F, INF, MIF, dan M. Kemudian untuk siswa dengan kemampuan komunikasi matematis sedang sebanyak 13 orang atau sebesar $45 \%$ yaitu siswa dengan kode AN, RS, MT, NPR, RR, AJA, AP, AF, FR, KI, D, SS dan M. Siswa dengan kemampuan komunikasi matematis rendah sebanyak 3 orang atau sebesar $10 \%$ yaitu siswa dengan kode SNF, MZ, dan VA. Dan siswa dengan kemampuan komunikasi matematis sangat rendah sebanyak 3 orang atau sebesar $10 \%$ yaitu siswa dengan kode MY, WZ dan HP.

Berdasarkan dari data yang telah diperoleh pada gambar 1 dan 2 dilakukan analisis antara kemampuan komunikasi matematis berdasarkan tingkat self-esteem yang dimiliki siswa. Diperoleh hasil dari data tersebut yaitu yang memiliki self-efsteem tinggi terdapat sebanyak 5 siswa diantaranya yaitu: yang memiliki kemampuan komunikasi matematis sangat tinggi yaitu sebanyak 2 siswa dengan kode IAK, dan ANP; dan yang memiliki kemampuan komunikasi matematis tinggi yaitu sebanyak 3 siswa dengan kode ARS, MNRF dan AZ.

Kemudian untuk siswa yang mempunyai self-esteem sedang sebanyak 20 siswa diantaranya yaitu: Yang memiliki kemampuan komunikasi matematis sangat tinggi yaitu sebanyak 2 siswa dengan kode NI dan NLM; yang memiliki kemampuan komunikasi matematis tinggi yaitu sebanyak 3 siswa dengan kode F, INF, dan MI; yang memiliki kemampuan komunikasi matematis sedang yaitu sebanyak 13 siswa dengan kode AN, RS, MT, NPR, RR, AJA, AP, AF, FR, KI, D, SS dan M; dan yang memiliki kemapuan komunikasi matematis rendah yaitu sebanyak 2 siswa dengan kode SNF dan MZ.

Sedangkan siswa yang self-esteem rendah terdapat 4 siswa dengan kemampuan komunikasi matematis rendah yaitu sebanyak 1 siswa dengan kode VA, dan dengan kemampuan komunikasi matematis sangat rendah yaitu sebanyak 3 siswa dengan kode M, WZ dan HP. Dari pembahasan diatas dapat disajikan dengan diagram batang berikut ini:

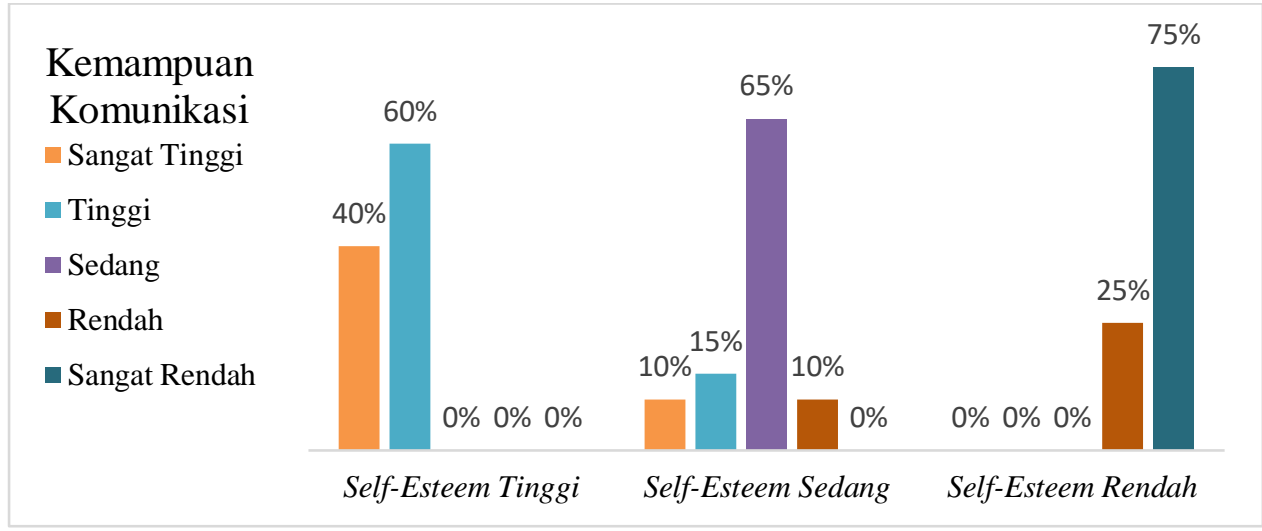

Gambar 3: Kemampuan Komunikasi Matematis Berdasarkan Tingkatan Self-Esteem

Berdasarkan gambar 3 di atas dapat diketahui bahwa siswa yang self-esteem tinggi memiliki kemampuan komunikasi matematis dengan dua kategori yaitu sangat tinggi dan tinggi. Siswa yang kemampuan komunikasi 
Vol 1 No 12020 Juli 2020

Jurnal AlphaEuclidEdu

matematis sangat tinggi sebanyak 2 orang atau sebesar 40\%, sedangkan siswa dengan kemampuan komunikasi matematis tinggi terdapat 3 orang atau sebesar $60 \%$.

Pada siswa yang self-esteem sedang memiliki kemampuan komunikasi matematis dengan empat kategori yaitu sangat tinggi, tinggi, sedang, dan rendah. Siswa yang memiliki kemampuan komunikasi matematis sangat tinggi sebanyak 2 orang atau sebesar 10\%, siswa dengan kemampuan komunikasi matematis tinggi sebanyak 3 orang atau sebesar $15 \%$, siswa dengan kemampuan komunikasi matematis sedang sebanyak 13 orang atau sebesar $65 \%$, sedangkan sebanyak 2 siswa atau sebesar $10 \%$ memiliki kemampuan komunikasi matematis rendah.

Siswa yang termasuk kategori self-esteem rendah memiliki kemampuan komunikasi matematis dengan dua kategori yaitu rendah dan sangat rendah. Siswa yang memiliki kemampuan komunikasi matematis rendah sebanyak 1 orang atau sebesar 25\%, sedangkan siswa dengan kemampuan komunikasi matematis sangat rendah sebanyak 3 orang atau sebesar $75 \%$.

Dari 29 siswa yang telah diberikan angket self-esteem dan tes kemampuan komunikasi matematis peneliti memilih masing-masing dua perwakilan siswa yang memiliki tingkat self-esteem tinggi yaitu IAK dan MNRF, sedangkan siswa yang memiliki tingkat self-esteem sedang ialah SNF dan SS, dan untuk siswa yang memiliki tingkat self-esteem rendah yaitu VA dan HP.

\subsection{Pembahasan}

\subsubsection{Analisis Hasil Tes Tertulis}

Proses Penelitian ini bertujuan untuk mendeskripsikan kemampuan komunikasi matematis menyelesaikan soal himpunan dikaji dari self-esteem di kelas VII SMP Islam Bawari Pontianak. Berdasarkan tujuan penelitian akan dibahas kemampuan komunikasi matematis siswa terhadap tingkatan self-esteem tinggi, sedang, maupun rendah. Hasil tes terhadap subjek penelitian yang memiliki tingkatan self-esteem menunjukkan bahwa masing-masing memiliki kemampuan menyelesaikan soal yang berbeda-beda. Dalam tes kemampuan komunikasi matematis ini yang perlu diperhatikan yaitu memahami konteks soal, menentukan ide matematis soal, dapat menghubungkan ide-ide matematis pada soal ke diagram venn, cara siswa dalam menggunakan simbol atau pemahaman siswa dalam notasi yang terdapat pada soal, cara siswa dalam menyelesaikan soal, serta membuat kesimpulan. Berikut ini dibahas mengenai kemampuan komunikasi matematis dalam menyelesaikan soal himpunan dikaji dari self-esteem yang didukung dengan data yang didapat dari hasil wawancara.

Kemampuan Komunikasi Matematis Siswa yang Memiliki Self-Esteem Tinggi dalam Menyelesaikan Soal Himpunan

Berdasarkan hasil penelitian secara keseluruhan siswa dengan tingkat self-esteem tinggi berjumlah sebanyak 5 orang siswa, dengan 2 orang siswa yang memiliki kemampuan komunikasi matematis sangat tinggi dan 3 orang siswa memiliki kemampuan komunikasi matematis tinggi. Berdasarkan hasil wawancara terhadap dua subjek yang dipilih secara acak yaitu IAK dan MNRF, menunjukkan bahwa masing-masing memiliki kemampuan komunikasi matematis yang berbeda-beda dalam menyelesaikan soal himpunan.

Untuk siswa dengan kode IAK secara umum dari hasil jawaban siswa pada soal nomor 2 siswa sudah bisa menggunakan ide-ide matematis pada soal, siswa sudah bisa menggunakan symbol atau notasi pada soal, sudah bisa menginterpretasikan simbol atau notasi pada soal, dan pada soal nomor 3 siswa sudah bisa menggunakan ide-ide matematis pada soal, siswa sudah bisa menggunakan simbol atau notasi pada soal, siswa sudah bisa membuat model matematika dari notasi-notasi atau istilahistilah yang terdapat pada soal, namun pada soal nomor 1 siswa mengalami kekeliruan saat menghubugkan ide-ide matematisnya ke dalam diagram venn, dan pada saat wawancara siswa dengan kode IAK tidak mengalami kesulitan dalam menjelaskan jawaban yang telah dikerjakannya. Siswa dapat membaca simbol atau notasi yang terdapat pada soal. Siswa dapat mengetahui kesalahan yang dikerjakannya. Pada dasarnya siswa sudah mampu memahami konteks soal yang diberikan.

Untuk siswa dengan kode MNRF secara umum dari hasil jawaban siswa pada soal nomor 1 sudah bisa dalam menggunakan ide-ide matematisnya dalam menghubungkan ke dalam diagram vennya, namun pada saat memberikan kesimpulan masih tidak tepat, untuk soal nomor 2 siswa sudah bisa menggunakan ide-ide matematis pada soal, siswa sudah bisa menggunakan simbol atau notasi pada soal, siswa sudah bisa menginterpretasikan simbol atau notasi pada soal, untuk soal nomor 3 siswa 
Vol 1 No 12020 Juli 2020

Jurnal AlphaEuclidEdu

belum bisa meggunakan notasi-notasi pada soal dalam membuat model matematika, siswa mengalami kekeliruan dalam menghitung ini disebabkan siswa belum bisa menggunakan ide-ide matematisnya dengan benar, dan pada saat wawancara siswa dengan kode MNRF mengatakan bahwa siswa tersebut cukup sulit mengerjakan soal pada nomor 3, pada saat menjelaskan kembali jawaban yang telah dikerjakannya siswa dengan kode MNRF tidak mengalami kesulitan pada soal nomor satu dan dua, dan soal nomor tiga pada bagian penyelesaian siswa kebingungan namun pada akhirnya dia menyadari bahwa siswa tersebut mengalami kesalahan dalam menghitung, Kemudian siswa sudah bisa membaca simbol atau notasi yang terdapat pada soal. Siswa dapat mengetahui kesalahan yang dikerjakannya. Pada dasarnya siswa sudah mampu memahami konteks soal yang diberikan.

Ketercapaian kemampuan komunikasi matematis siswa yang mempunyai self-esteemnya tinggi sebesar $80 \%$. Dari hasil wawancara kedua subjek dan penjelasan di atas dapat disimpulkan bahwa siswa ini sangat percaya diri dan optimis serta siswa dapat mengetahui kesalahan yang dimilikinya dalam menyelesaiakn soal himpunan tersebut.

Kemampuan Komunikasi Matematis Siswa yang Memiliki Self-Esteem Sedang dalam Menyelesaikan Soal Himpunan

Berdasarkan hasil penelitian secara keseluruhan siswa dengan tingkat self-esteem sedang berjumlah 20 orang, dengan 2 orang siswa yang memiliki kemampuan komunikasi matematis sangat tinggi, 3 orang siswa memiliki kemampuan komunikasi matematis tinggi, 13 orang siswa memiliki kemampuan komunikasi matematis sedang, dan 2 orang siswa memiliki kemampuan kominikasi matematis rendah. Berdasarkan hasil wawancara terhadap dua subjek yang dipilih secara acak yaitu SNF dan SS, menunjukkan bahwa masing-masing memiliki kemampuan komunikasi matematis yang berbeda-beda dalam menyelesaikan soal himpunan.

Untuk siswa dengan kode SNF secara umum dari hasil jawaban siswa pada soal nomor 1 siswa sudah bisa dalam menggunakan ide-ide matematisnya dalam menghubungkan ke dalam diagram vennya, pada nomor 2 siswa tidak mengerjakan, untuk nomor 3 siswa belum bisa menyajikan ide-ide matematis pada soal dengan lengkap, dan pada saat wawancara siswa dengan kode SNF mengalami kesulitan dalam menjelaskan kembali hasil yang telah dikerjakannya, siswa belum bisa membaca simbol atau notasi pada soal nomor 1, dan siswa kurang mampu memahami konteks soal.

Untuk siswa dengan kode SS secara umum dari hasil jawaban siswa pada soal nomor 1 siswa sudah bisa dalam menggunakan ide-ide matematisnya dalam menghubungkan ke dalam diagram vennya, untuk soal nomor 2 siswa belum bisa menggunakan ide-ide matematis pada soal, siswa belum bisa menggunakan symbol atau notasi pada soal, siswa belum bisa menginterpretasikan symbol atau notasi pada soal, untuk soal nomor 3 siswa sudah bisa menggunakan ide-ide matematis pada soal, siswa sudah bisa menggunakan symbol atau notasi pada soal, siswa belum bisa membuat model matematika dari notasi-notasi atau istilah-istilah yang terdapat pada soal, dan pada saat wawancara siswa dengan kode SS cukup bisa dalam menjelaskan kembali jawaban yang telah dikerjakannya pada soal 1 dan 3, dan untuk nomor 2 siswa bisa menjelaskan namun tidak yakin, Kemudian siswa cukup bisa membaca simbol atau notasi yang terdapat pada soal. Siswa cukup mampu memahami konteks soal. Ketercapaian kemampuan komunikasi matematis yang dimiliki siswa self-esteem sedang sebesar 56\%.

Kemampuan Komunikasi Matematis Siswa yang Memiliki Self-Esteem Rendah dalam Menyelesaikan Soal Himpunan

Berdasarkan hasil penelitian secara keseluruhan siswa dengan tingkat self-esteem rendah berjumlah 4 orang, dengan 1 orang siswa yang mempunyai kemampuan komunikasi matematis rendah dan 3 orang siswa yang kemampuan komunikasi matematis sangat rendah. Berdasarkan hasil wawancara terhadap dua subjek yang dipilih secara acak yaitu VA dan HP, menunjukkan bahwa masing-masing memiliki kemampuan komunikasi matematis yang berbeda-beda dalam menyelesaikan soal himpunan.

Untuk siswa dengan kode VA secara umum dari hasil jawaban siswa pada soal nomor 1 siswa sudah bisa dalam menggunakan ide-ide matematisnya dalam menghubungkan ke dalam diagram vennya, pada soal nomor 2 siswa hanya menuliskan informasi pada soal, untuk soal nomor 3 siswa juga hanya menuliskan informasi pada soal namun tidak lengkap, dan pada saat wawancara siswa dengan kode VA mengalami kesulitan dalam menjelaskan kembali hasil yang telah dikerjakannya, siswa cukup 
Vol 1 No 12020 Juli 2020

Jurnal AlphaEuclidEdu

kesulitan dalam membaca simbol atau notasi pada soal, dan siswa kurang mampu memahami konteks soal.

Untuk siswa dengan kode HP secara umum dari hasil jawaban siswa pada soal nomor 1 siswa sudah bisa dalam menggunakan ide-ide matematisnya dalam menghubungkan ke dalam diagram vennya, pada nomor 2 siswa tidak mengerjakan, untuk nomor 3 siswa juga tidak mengerjakannya, dan pada saat wawancara siswa dengan kode HP mengalami kesulitan dalam menjelaskan kembali hasil yang telah dikerjakannya, siswa belum bisa membaca simbol atau notasi pada soal, dan siswa kurang mampu memahami konteks soal. siswa dengan kode HP ini pada saat wawancara juga berkata bahwa dia kurang menyukai pelajaran matematika, dan dia juga berkata bahwa ketika mengalami kesulitan dalam pelajaran ini dia tidak mau bertanya dikarenakan takut dan malu sehingga hal ini juga membuat dirinya semakin tidak mengerti pelajaran matematika. Ketercapaian kemampuan komunikasi matematis siswa yang self-esteemnya rendah sebesar $20 \%$.

Berdarkan penjelasan di atas siswa yang self-esteemnya tinggi relatif mempunyai kemampuan komunikasi matematis yang tinggi, sedangkan untuk siswa yang self-esteemnya sedang mempunyai kemampuan komunikasi matematis sedang, dan siswa yang self-esteem rendah mempunyai kemampuan komunikasi matematis rendah. Penjelasan tersebut sesuai dengan pernyataan Baumaester, dkk (2003) yang menyatakan bahwa self-esteem meningkat maka meningkat juga prestasi akademik, hal ini juga sesuai dengan hasil penelitian Mahani (2019) yang menunjukkan bahwa self-esteem yang tinggi memiliki kemampuan komunikasi matematis yang lebih bagus dibandingkan self-esteem yang sedang maupun yang rendah. Pernyataan Braumaster (2003) dan Mahani (2019) sejalan dengan teori yang dinyatakan oleh Körük (Karadag, 2017) yang menyatakan bahwa self-esteem adalah faktor penting dalam meningkatkan prestasi akademik ini diperkuat dengan pernyatan Ghufron dan Risnawita (2018: 44) yang mengatakan bahwa self-esteem dapat berdampak pada perkembangan potensial yang dimiliki seseorang, sehingga dapat dikatakatan bahwa self-esteem berperan dalam tingkatan pencapaian yang akan diperoleh seseorang.

Self-esteem berperan penting pada perkembangan potensial yang dimiliki seseorang, untuk itu perlu diperhatikan dan dikembangan. Self-esteem akan terlihat dari tindakan yang akan dilakukan sesorang melalui proses tertentu bukan terbentuk dengan sendirinya, ada tahapan-tahapan tertentu yang harus dilalui oleh individu sehingga dapat meyakini kemampuan mereka terhadap kegiatan akademis maupun tugas-tugas tertentu yang akan mereka lakukan.

\section{Kesimpulan}

Dari uraian deskripsi data beserta analisis data dapat disimpulkan bahwa siswa yang self-esteem tinggi relatif mempunyai kemampuan komunikasi matematis tinggi, sedangkan untuk siswa yang self-esteemnya sedang mempunyai kemampuan komunikasi matematis sedang, dan yang memiliki self-esteem rendah mempunyai kemampuan komunikasi matematis yang rendah. Siswa dengan tingkat self-esteem tinggi, memiliki kemampuan yang relatif mampu memahami konteks soal dalam menyajikan kembali informasi yang diperoleh dari soal, siswa sudah mampu dalam menggunakan ide-ide matematis dan dapat menghubungkannya pada diagram Venn, siswa dapat menginterpretasikan istilah-istilah atau notasi-notasi yang terdapat pada soal, siswa dapat menggunakan simbol atau notasi yang terdapat pada soal, siswa dapat membaca simbol-simbol yang terdapat pada soal dan pada dasarnya siswa sudah mampu memahami konsep soal yang dikerjakannya; Siswa dengan tingkat self-esteem sedang, memiliki kesulitan dalam menyelesaikan soal, sehingga jawaban yang diberikan tidak lengkap dan kurang tepat dengan informasi yang terdapat pada soal, kemudian siswa sudah mampu dalam menggunakan ide-ide matematis dan dapat menghubungkannya pada diagram venn, siswa cukup bisa menginterpretasikan istilah-istilah atau notasi-notasi yang terdapat pada soal, siswa cukup bisa menggunakan simbol atau notasi yang terdapat pada soal, siswa cukup bisa membaca simbol-simbol yang terdapat pada soal dan pada dasarnya siswa cukup mampu memahami konsep soal yang dikerjakannya; Siswa dengan tingkat self-esteem rendah, sulit untuk memahami makna dari soal dan tidak mampu dalam menyelesaikan soal yang diberikan, siswa cukup mampu dalam menggunakan ide-ide matematis dan dapat menghubungkannya pada diagram venn, siswa belum bisa dalam menginterpretasikan istilah-istilah atau notasinotasi yang terdapat pada soal dan siswa belum bisa menggunakan simbol atau notasi yang terdapat pada soal, siswa tidak dapat membaca simbol-simbol atau notasi yang terdapat pada soal dan pada dasarnya siswa belum mampu memahami konsep soal yang dikerjakannya. 
Vol 1 No 12020 Juli 2020

Jurnal AlphaEuclidEdu

\section{Referensi}

Arikunto, Suharsimi. 2009. Manajemen Penelitian. Jakarta: Rineka Cipta.

Baumeister, R. F., Campbell, J. D., Krueger, J. I., \& Vohs, K. D. (2003). Does high self-esteem cause better performance, interpersonal success, happiness, or healthier lifestyles? Psychological Science in the Public Interest, 4(1), 1-44.

Fadhillah, S. 2012. Meningkatkan Self-Esteem Siswa SMP dalam Matematika melalui Pembelajaran dengan Pendekatan Open Ended. Jurnal Pendidikan MIPA. Vol 13 (2): 34-41

Ghufron, M.N, Risnawita, R.S. 2018. Teori-teori Psikologi. Jogjakarta: AR-RUZZMEDIA.

Happy, N. \& D. B. Widjajanti. 2014. Keefektifan PBL ditinjau dari kemampuan Berfikir Kritis dan Kreatif Matematis, serta Self-Esteem siswa SMP. Jurnal Riset Pendidikan Matematika. Vol. 1 No. 1: 48-57

Hendriana, Heris, dkk. 2018. Hard Skills dan Soft Skills Matematika Siswa. Bandung: PT Refika Aditama

Karadag, E. (2017). The Factors Effecting Students Achievements: Meta-Analysis Of Empirical Studies. Turki: Springer Internasional Publishing.

Lackner, P. 2015. A Meta-Analysis Investigating The Correlation Between Self-Esteem and Academic Achievement In Americans: Mergin Social Psychology and a Jesuit Education.

Mahani, I. (2019). The Effect of Self-Esteem on Students' Mathemtical Communication Skills. Al-Jabar: Jurnal Pendidikan Matematika. Vol. 10, No. 1.

NCTM. 2000. Principles and Standards for School Mathematics. Reston, VA: NCTM.

Pujiastuti, H. 2014. Pembelajaran Inquiry C0-peration Model untuk Meningkatkan Kemampuan Pemecahan Masalah, Komunikasi, dan Sel-Esteem Matematis Siswa SMP. Tesis UPI Bandung: tidak diterbitkan.

Riduwan. 2010. Skala Pengukuran Variabel-variabel Penelitian. Bandung: Alfabeta.

Umar, Wahid. 2012. Membangun Kemampuan Komunikasi Matematis dalam Pembelajaran Matematika. Jurnal Ilmiah Program Studi Matematika STKIP Siliwangi Bandung(Infinity) Vol 1, No.1.

Verdianingsih, E. 2017. Self-Esteem Dalam Pembelajaran Matematika. Jurnal Pendidikan, Pembelajaran dan Teknologi. Vol. 3, No. 2

Yeshodhara, K.\& Vishalakshi. 2012. Relathionship Between Self-Esteem and Academic Achievement Of Secondary School Students. Indian Journal Of Applied research. Vol.1 (12) 